\title{
Ungulate herbivory modifies the effects of climate change on mountain forests
}

\author{
M. Didion • A. D. Kupferschmid • \\ A. Wolf • H. Bugmann
}

Received: 28 August 2009 / Accepted: 27 January 2011 / Published online: 15 April 2011

(C) The Author(s) 2011. This article is published with open access at Springerlink.com

\begin{abstract}
Recent temperature observations suggest a general warming trend that may be causing the range of tree species to shift to higher latitudes and altitudes. Since biotic interactions such as herbivory can change tree species composition, it is important to understand their contribution to vegetation changes triggered by climate change. To investigate the response of forests to climate change and herbivory by wild ungulates, we used the forest gap model ForClim v2.9.6 and simulated forest development in three climatically different valleys in the Swiss Alps. We used altitudinal transects on contrasting slopes covering a wide range of forest types from the cold (upper) to the dry (lower) treeline. This allowed us to investigate (1) altitudinal range shifts in response to climate change, (2) the consequences for tree species composition, and (3) the combined effect of climate change and ungulate herbivory. We found that ungulate herbivory changed species composition and that both basal area and stem numbers decreased with increasing herbivory intensity. Tree species responded differently to the change in climate, and their ranges did not change concurrently, thus causing a succession to new stand types. While climate change partially compensated for the reductions in basal area caused by ungulate herbivory, the combined effect of these two agents on the mix of the dominant species and forest type was non-compensatory, as browsing selectively excluded species from establishing or reaching dominance and altered competition patterns, particularly for light. We conclude that there is an urgent need for adaptive forest management strategies that address the joint effects of climate change and ungulate herbivory.
\end{abstract}

M. Didion (凶) · A. D. Kupferschmid · A. Wolf · H. Bugmann

Forest Ecology, Institute of Terrestrial Ecosystems, Department of Environmental Sciences, Swiss Federal Institute of Technology ETH, Universitätstr. 22, CH 8092 Zurich, Switzerland e-mail: markus_didion@alumni.sfu.ca

Present Address:

M. Didion

ALTERRA, Wageningen University and Research Centre,

P.O. Box 47, 6700AA Wageningen, The Netherlands 


\section{Introduction}

The general anthropogenic warming trend (IPCC 2007) may be causing tree species to shift to higher latitudes and altitudes (Davis and Shaw 2001; Theurillat and Guisan 2001; Walther et al. 2002). It is expected that some previously unforested regions at high latitudes and altitudes (cold treeline) may become more suitable for tree growth, whereas some low-latitude and low-altitude areas may not sustain forest cover any more due to an increase in droughts (Cairns et al. 2007; Gehrig-Fasel et al. 2007). However, the range shifts of tree species depend, in addition to climate, on various other natural and anthropogenic factors such as seed availability, resource availability and land use (Walther et al. 2002; Thuiller et al. 2005). Feeding on aboveground plant tissue by wild ungulates such as deer and reindeer has been identified as an important driver for the local position of treelines in mountain and high-latitude ecosystems (e.g., Kullman 2001; Grace et al. 2002; Moen et al. 2004). In these, but also in other forest ecosystems, ungulate herbivores can prevent tree establishment entirely or modify the tree species mix and thus influence long-term forest development (Augustine and McNaughton 1998; Côté et al. 2004).

Forest development in response to changes in climate has been explored in a wide range of modeling studies (e.g., Wallentin et al. 2008; Bugmann 2003; Lexer et al. 2002). However, the role of ungulate herbivores as a driver of forest succession in response to a changing climate has, to our knowledge, not been addressed in modeling studies. We aimed to fill this gap by using the forest gap model ForClim (Didion et al. 2009c) to simulate forest development under climate change and different ungulate browsing pressure.

The objective of this study was to examine the combined effects of climate change and ungulate browsing along elevation transects. We selected three climatically different valleys in the Swiss Alps to investigate (1) altitudinal range shifts in response to climate change, (2) the consequences for tree species composition, and (3) the combined effect of climate change and ungulate browsing.

\section{Material and methods}

\subsection{Study area}

We selected transects across three valleys in climatically different regions of the Swiss Alps: (1) Western Central Alps (dry, warm summers and cold winters); (2) Northern Central Alps (moist, cool summers and cold winters); and (3) Southern Alps (wet, warm summers and mild winters). All transects ran from a predominantly southfacing to a predominantly north-facing slope via the valley bottom.

\subsubsection{Western Central Alps}

The Anniviers valley (Val d'Anniviers) is a side valley of the Rhone River valley in the Valais, Western Central Alps. The catchment is ca. $255 \mathrm{~km}^{2}$ in size and ranges from 500 to $4,400 \mathrm{~m}$ a.s.l. The transect crosses the valley in a north-east to south-west direction from a small peak near Mt. Illhorn (ca. 2,300 m; 46 $15^{\prime} \mathrm{N}, 7^{\circ} 36^{\prime} \mathrm{E}$ ) to Mt. La Brinta (ca. 2,600 m; 46 $13^{\prime} \mathrm{N}, 7^{\circ} 32^{\prime} \mathrm{E}$ ) via the village of Fang in the valley bottom (ca. $850 \mathrm{~m}$ ). This valley is characterized by a continental climate with cold winters and 
relatively dry and warm summers (Table 1$)$. In the valley bottom where precipitation is low (i.e., annually ca. 500-700 mm) and the dry treeline is approached, current forests are composed mainly of drought-resistant species, such as Quercus spp. and Pinus sylvestris (Lock et al. 2003). With increasing elevation, the dominant species change to Picea abies (high-montane to subalpine, ca. 1,000-1,800 m) and further up to Larix deciduas-Pinus cembra (upper subalpine ca. 1,800 m to treeline ca. 2,500 m; Gödickemeier 1998; Ott et al. 1997). The transition between Pinus and Picea forests is found around $200-400 \mathrm{~m}$ lower on the colder north-facing slope than on the warmer south-facing slope (Ott et al. 1997).

\subsubsection{Northern Central Alps}

The Tuors valley (Val Tuors) is located in the transition zone between the northern pre-alpine and the central alpine area in Graubünden. The catchment is ca. $57 \mathrm{~km}^{2}$ in size and ranges from 1,350 to $3,350 \mathrm{~m}$ a.s.l. in altitude. The transect runs in a straight north-south direction from Piz Valmela (ca. 2,700 m; 46 $39^{\prime} \mathrm{N}, 9^{\circ} 47^{\prime} \mathrm{E}$ ) via the village of Tuors Davant in the valley of the Tuors (ca. 1,700 m) to Piz Darlux (ca. 2,600 m; 46 $37^{\prime} \mathrm{N}, 9^{\circ} 47^{\prime} \mathrm{E}$ ). Cold winters with high amounts of snow (Table 1) restrict the species diversity and successional pathways in the montane and subalpine forests (Ott et al. 1997). The dominant species change with elevation from $P$. abies at the high-montane and lower subalpine region (i.e., up to ca. 2,000 m) of the valley (Didion et al. 2009b; Ott et al. 1997) to L. decidua and P. cembra in the upper subalpine level up to treeline (ca. 2,500 m; Ott et al. 1997).

\subsubsection{Southern Alps}

The Maggia valley (Valle Maggia) is located in the northern part of the Ticino in the Southern Swiss Alps. The catchment covers ca. $574 \mathrm{~km}^{2}$ and ranges from 200 to 3,200 $\mathrm{m}$ a.s.l. The transect runs in a north-south direction from Piz Spluga (ca. 2,200 m; 46¹9' N, $8^{\circ} 39^{\prime}$ E) via the Maggia River (ca. 400 m) to Piz Güi (ca. 2,200 m;

Table 1 Long-term mean seasonal temperature $\left({ }^{\circ} \mathrm{C}\right)$ and precipitation sum $(\mathrm{cm})$ of the current climate (1961-2000) and mean anomalies $\left({ }^{\circ} \mathrm{C}\right.$ and \% precipitation, respectively) for future steady state climate (cf. Section 2.3.2)

\begin{tabular}{|c|c|c|c|c|c|c|c|c|}
\hline & \multicolumn{4}{|c|}{ Temperature } & \multicolumn{4}{|c|}{ Precipitation } \\
\hline & Spring & Summer & Fall & Winter & Spring & Summer & Fall & Winter \\
\hline \multicolumn{9}{|c|}{ Anniviers valley } \\
\hline $800 \mathrm{~m}$ & 8.0 & 16.7 & 8.6 & -0.2 & 15.5 & 19.0 & 17.2 & 19.1 \\
\hline $2650 \mathrm{~m}$ & -3.6 & 5.5 & 0.3 & -7.2 & 26.8 & 33.5 & 26.0 & 25.9 \\
\hline Anomalies & +4.1 & +5.9 & +4.8 & +3.6 & -6.3 & -15.7 & -8.3 & -1.4 \\
\hline \multicolumn{9}{|l|}{ Tuors valley } \\
\hline $1650 \mathrm{~m}$ & 1.7 & 10.8 & 3.8 & -5.1 & 21.4 & 36.7 & 25.5 & 15.9 \\
\hline $2700 \mathrm{~m}$ & -4.7 & 4.7 & -1.1 & -9.6 & 25.8 & 44.0 & 29.3 & 21.0 \\
\hline Anomalies & +3.9 & +5.1 & +4.7 & +3.6 & +0.4 & -10.0 & -3.0 & +4.8 \\
\hline \multicolumn{9}{|l|}{ Maggia valley } \\
\hline $350 \mathrm{~m}$ & 11.0 & 19.7 & 11.3 & 2.5 & 47.8 & 49.9 & 60.1 & 22.7 \\
\hline $2200 \mathrm{~m}$ & -1.1 & 8.2 & 2.2 & -5.7 & 60.8 & 57.9 & 67.1 & 37.5 \\
\hline Anomalies & +4.1 & +5.3 & +4.6 & +3.8 & +5.1 & -27.6 & +3.3 & +11.9 \\
\hline
\end{tabular}

Data were presented for the lowest and highest point of each transect 
$\left.46^{\circ} 15^{\prime} \mathrm{N}, 8^{\circ} 37^{\prime} \mathrm{E}\right)$. The climate in this part of the Southern Alps is characterized by warm summers, mild winters and high annual precipitation (Table 1) of uneven distribution including heavy rainfall events interrupted by extended periods of drought in spring and summer. This is characteristic of the so-called insubrian region; it allows for a diverse mix of deciduous tree species at low to medium elevations (Gobet et al. 2000). In the colline belt below ca. $700 \mathrm{~m}$, Castanea sativa, Fagus sylvatica and Quercus spp. are expected to dominate (Ott et al. 1997). The montane belt (ca. 700-1,600 m) is dominated by F. sylvatica at the lower and P. abies together with Abies alba at the upper level (Didion et al. 2009b; Ott et al. 1997). The subalpine region between ca. 1,600 and 2,100 $\mathrm{m}$ is dominated mainly by P. abies and L. decidua (Ott et al. 1997).

\subsection{Gap model ForClim}

The gap model ForClim simulates the establishment, growth, and mortality of trees on multiple small forest patches to derive stand-scale dynamics (Bugmann 1996). Tree growth is specified as a species-specific maximum that is reduced to a realized growth rate by taking into account key limiting factors (temperature, drought, light availability, and nitrogen availability). Trees are established as saplings with a diameter at breast height $(\mathrm{dbh})$ of $1.27 \mathrm{~cm}$, whereby the number of new trees is a function of species-specific responses to winter temperature, light availability, growing degree-days, and browsing pressure (Bugmann 1994). ForClim performed well in several studies comparing simulated forests with local, site specific forest data (Didion et al. 2009b, c; Risch et al. 2005), and also with potential natural vegetation along large temperature and precipitation gradients within and between various mountain regions (Didion et al. 2009c; Bugmann and Solomon 2000; Shao et al. 2001). As input the model requires monthly means and standard deviations of temperature and precipitation as well as their cross-correlation (Bugmann 1994).

The model allows to account for the effect of slope and aspect on the amount of incident radiation, which affects evapotranspiration (cf. Section 3.3.3 in Bugmann 1994 and references therein). The parameter kSlAsp [-2..+2] is used to modify potential evapotranspiration (PET; Bugmann 1994, eq.[3.74]) by decreasing PET by a maximum of $12.5 \%$ on steep north-facing slopes $(k S l A s p=-2)$ and by increasing PET by a maximum of $25 \%$ on steep south-facing slopes $(k S l A s p=+2)$.

In our study, we revised ForClim model version 2.9.5 (Didion 2009; Didion et al. 2009a) by refining the relationship between browsing pressure and browsing-induced mortality. This resulted in the new model version 2.9.6 (for a detailed description see Appendix I and III in Didion 2009). In the new model version, the relationship between browsing pressure $(\mathrm{kBr} P r)$ and browsing-induced mortality of seedlings and saplings $(k B r P)$ is

$$
k B r P=\left(\frac{k B r P r}{100}\right)^{a_{\mathrm{kBrow}}}
$$

where $k B r P r$ ranges from $0 \%$ (no browsing) to $100 \%$ (heavy browsing where no sapling establishment is possible) and $a_{k \text { Brow }}$ is the exponent for five levels of tree species browsing sensitivity $(k B r o w=[1 . .5])$. The parameter $k$ Brow is a measure of the browsing related survival probability of seedlings and saplings before reaching a $\mathrm{dbh}$ of $1.27 \mathrm{~cm}$, which is the size at which trees establish in ForClim. This corresponds 
to a tree height of at least $1.40 \mathrm{~m}$, which is above the browsing limit of ungulates in the European Alps (Eiberle and Nigg 1987). kBrow was revised based on an extensive literature search and expert opinion, and considers (a) the browsing preference of ungulates $(B P U),(\mathrm{b})$ the rate of height growth of seedlings $(R H G),(\mathrm{c})$ the ability of a tree species to compensate for tissue losses $(C A)$, and (d) the survival probability after browsing ( $S P$, Table 2; cf. Appendix III in Didion 2009). The exponent $a_{k B r o w}$ (Eq. 1) was set to 4, 2, 1, 0.5 and 0.25 for kBrow values of 1 to 5, respectively (Fig. 1; for details see Appendix III in Didion 2009).

The model includes 30 European tree species (Fig. 1, Table 2) and assumes unlimited seed availability of all species. As $C$. sativa is mostly absent in the northern part of the Swiss Alps (Brassel and Brändli 1999; EAFV and BFL 1988), we assumed that this species will remain absent due to its heavy seeds. Thus, we excluded C. sativa from the species pool at the two transects in the Western (i.e., Anniviers valley)

Table 2 Species-specific sensitivity to browsing: Estimations of "BPU": browsing preference by ungulates with 1 (unpalatable) and 5 (highly palatable and preferred browsed)

\begin{tabular}{lllllll}
\hline Species & BPU & RHG & CA & SP & $\mu$ & kBrow \\
\hline Abies alba & 5 & 4 & 5 & 4 & 4.60 & 5 \\
Larix decidua & 3 & 2 & 3 & 5 & 3.20 & 3 \\
Picea abies & 1 & 3 & 4 & 5 & 2.80 & 2 \\
Pinus cembra & 3 & 5 & 4 & 4 & 3.80 & 4 \\
Pinus montana & 1 & 4 & 4 & 5 & 3.00 & 3 \\
Pinus sylvestris & 2 & 3 & 4 & 5 & 3.20 & 3 \\
Taxus baccata & 5 & 5 & 5 & 3 & 4.60 & 5 \\
Acer campestre & 5 & 3 & 3 & 2 & 3.60 & 4 \\
Acer platanoides & 5 & 2 & 3 & 3 & 3.60 & 4 \\
Acer pseudoplatanus & 5 & 2 & 3 & 3 & 3.60 & 4 \\
Alnus glutinosa & 2 & 1 & 3 & 1 & 1.80 & 1 \\
Alnus incana & 2 & 1 & 3 & 1 & 1.80 & 1 \\
Alnus viridis & 2 & 1 & 3 & 1 & 1.80 & 1 \\
Betula pendula & 2 & 1 & 1 & 2 & 1.60 & 1 \\
Carpinus betulus & 4 & 2 & 2 & 1 & 2.60 & 2 \\
Castanea sativa & 1 & 3 & 1 & 1 & 1.40 & 1 \\
Corylus avellana & 4 & 1 & 1 & 1 & 2.20 & 2 \\
Fagus sylvatica & 3 & 3 & 4 & 4 & 3.40 & 3 \\
Fraxinus excelsior & 5 & 2 & 3 & 2 & 3.40 & 3 \\
Populus nigra & 4 & 1 & 3 & 1 & 2.60 & 2 \\
Populus tremula & 4 & 1 & 3 & 1 & 2.60 & 2 \\
Quercus petraea & 4 & 2 & 3 & 5 & 3.60 & 4 \\
Quercus pubescens & 4 & 3 & 3 & 4 & 3.60 & 4 \\
Quercus robur & 4 & 2 & 3 & 5 & 3.60 & 4 \\
Salix alba & 5 & 1 & 1 & 1 & 2.60 & 2 \\
Sorbus aria & 5 & 4 & 3 & 3 & 4.00 & 4 \\
Sorbus aucuparia & 5 & 2 & 3 & 3 & 3.60 & 4 \\
Tilia cordata & 3 & 3 & 2 & 3 & 2.80 & 2 \\
Tilia platyphyllos & 3 & 3 & 2 & 3 & 2.80 & 2 \\
Ulmus glabra & 5 & 2 & 2 & 3 & 3.40 & 3 \\
\hline RHG rate & & & & & & \\
\end{tabular}

$R H G$ rate of height growth with 1 (fast growing) and 5 (slow growing); $C A$ compensation ability regarding tissue losses with 1 (high) and 5 (low); SP survival probability after browsing with 1 (high) and 5 (low); $\mu$ weighted mean of BPU (double weight), RHG, CA and SP; $k$ Brow derived from $\mu$ as used in the current ForClim v2.9.6. For details see Appendix III Didion (2009) 
Fig. 1 Relationship between mortality of tree seedlings and saplings (browsing probability, $k B r P$ ) and browsing pressure $(\mathrm{kBrPr})$. Mortality is calculated according to Eq. 1 for five levels of $a_{k \text { Brow }}$ that depend on the species sensitivity to browsing ( $k$ Brow (Table 2), with $a_{k \text { Brow }}=0.25$ for $k$ Brow $=5$, i.e., most sensitive, $a_{k \text { Brow }}=0.5$ for $k$ Brow $=4, a_{k \text { Brow }}=1$ for $k$ Brow $=3, a_{k \text { Brow }}=2$ for $k$ Brow $=2$ and $a_{k \text { Brow }}=4$ for kBrow $=1$, i.e., least sensitive) before reaching a dbh of $1.27 \mathrm{~cm}$ (cf. Appendix III in Didion 2009)

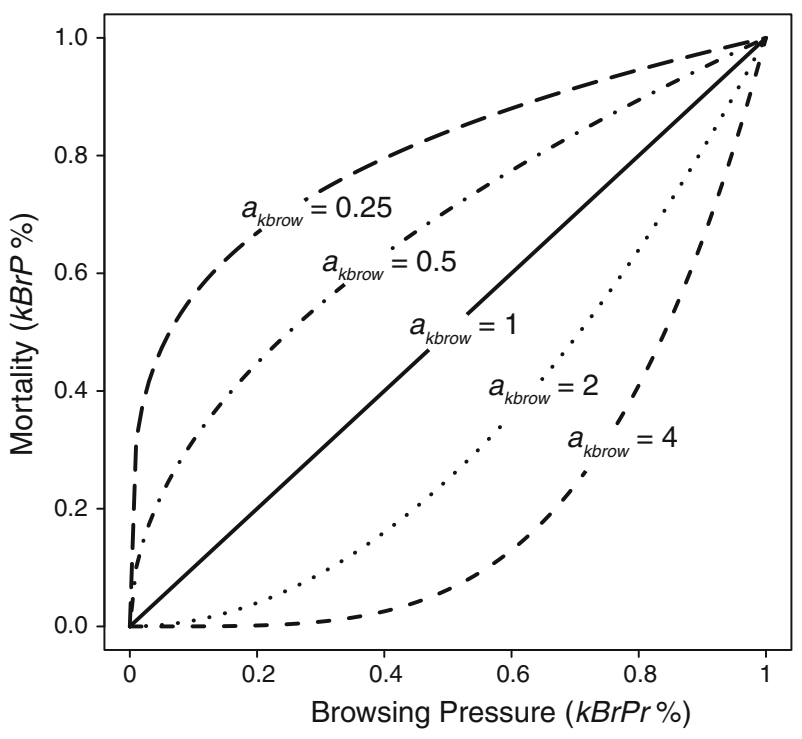

and Eastern (i.e., Tuors valley) Central Alps. However, in the Southern Alps (i.e., Maggia valley) C. sativa is a common tree species and was therefore included in the species pool for the simulations. Since the three Quercus species that are included in the model, i.e., Quercus petraea, Quercus pubescens and Quercus robur, have similar traits and are known to hybridize (Aas and Friedrich 1991), we subsumed them under Quercus spp. in the presentation of the results. Similarly, we combined Acer campestre and Acer platanoides as Acer spp.

\subsection{Climate data}

\subsubsection{Current climate}

We obtained monthly data for mean temperature and precipitation sum from the database of the Land Use Dynamics Research Group at the Swiss Federal Institute for Forest, Snow and Landscape Research. The database contains climate data for the period from 1960 to 2006 interpolated to a 1-ha grid across Switzerland based on the DAYMET model (Thornton et al. 1997). In order to derive temperature and precipitation data representing the current climate along each valley transect, we used the following procedure: First we selected from the respective catchment area those 1-ha grid cells that were within the altitudinal range of the transect and aggregated them into 50-m elevation bands. This resulted in a dataset of daily temperature and precipitation sum representative for each 50-m elevation band. We then calculated for each of those elevation bands the long-term monthly means (1961-2006), standard deviations and cross-correlations of mean temperature and precipitation sum (Fig. 2, Table 1). This approach eliminated potential inaccuracies occurring when single grid cells (i.e., only those intersected by a transect) are chosen from interpolated climate data. Due to differences in topography, the transects in the three valleys comprised different numbers of 50-m elevation bands: 68 bands (leading 

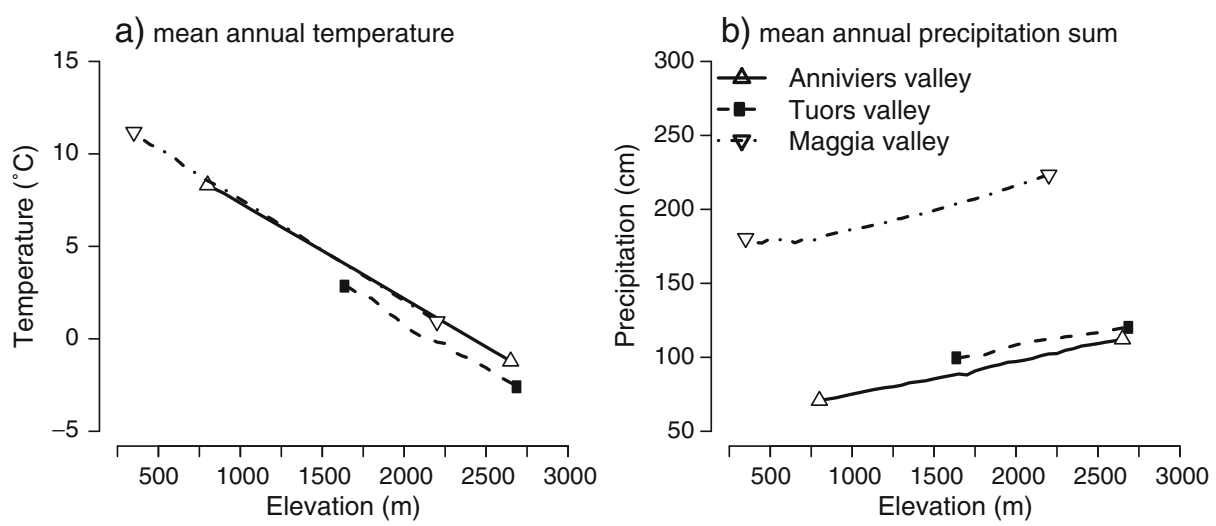

Fig. 2 Long-term annual mean temperature and precipitation sum by 50-m elevation bands in the three examined catchments based on interpolated climate data from 1960 to 2006 obtained from the Land Use Dynamics Research Group at the Swiss Federal Institute for Forest, Snow and Landscape Research

to simulation plots) for the transect in the Anniviers valley, 42 in the Tuors valley and 75 in the Maggia valley.

To represent the change in aspect and slope along the transects, we used the model parameter $k S l A s p$ (cf. Section 2.2). Using the different number of 50-m elevation bands on the north- and south-facing slopes, we linearly interpolated the range of $k S l A s p$ on each slope from north facing top $(k S l A s p=-2)$ passing the valley bottom $(k S l A s p=0)$ to the south-facing top $(k S l A s p=+2)$.

\subsubsection{Future climate}

To represent the anticipated change in climate in each of the three study regions, we used the regionalized climate change projections of the Institute for Atmospheric and Climate Science, ETH Zürich provided within the ENSEMBLES project (Hewitt and Griggs 2004; http://ensembles-eu.metoffice.com). For this dataset, projected climate change for the A1B scenario of the IPCC AR4 (IPCC 2007) was regionalized to a $10 \times 10 \mathrm{~km}$ grid, and transient climate change was simulated until the year 2099 .

We derived climate change scenarios for each transect based on the data from the nine $10 \times 10 \mathrm{~km}$ cells of the ENSEMBLES dataset that covered and surrounded each study area. We used the periods from 1961 to 1990 as baseline and the years 2075 to 2099 as representative years for the future climate and calculated the following climate anomalies based on the average monthly temperature and precipitation sum of these two periods:

1. Temperature anomalies for the seasonal mean (Table 1) and the standard deviation of the seasonal mean using the absolute difference between baseline and future temperatures;

2. Seasonal precipitation anomalies as the relative difference (percent; Table 1) between the baseline and the future precipitation both for the mean and the standard deviation; 
3. The anomalies of the monthly cross-correlations using the absolute difference between the corresponding values for the two periods (baseline and future climate).

The anomalies of the means, standard deviations, and cross-correlations were added (in case of absolute differences) and multiplied (in case of relative differences) to the current climate (Section 2.3.1), and the weather generator of ForClim (cf. Bugmann 1996) was used to derive realizations of a future climate in the plots along the three transects. As future climate is typically not projected by GCMs post-2100, we assumed here that it remains constant after 2100, thus simulating the long-term impact of the generally predicted warming trend.

\subsection{Simulation experiments}

Forest succession for a total of 6,100 years was simulated for each plot along the three transects (Section 2.3.1), as follows:

\subsubsection{Spin-up for 3,000 years under current climate}

Starting from bare ground, forest succession was simulated for 3,000 years under current climate to ensure that the simulated forest was in equilibrium with climate prior to imposing scenarios of changes in browsing and climate. The browsing pressure ( $\mathrm{kBrPr}$ ) was assumed to amount to $20 \%$ (cf. Eq. 1, Fig. 1), which represents a moderate intensity that approximates an average browsing intensity in Swiss forests (Didion et al. 2009c). This spin-up simulation was used for all of the following scenarios in order to have identical starting conditions for the browsing and climate change scenarios.

\subsubsection{Browsing and climate change scenarios}

Following the spin-up, browsing pressure $(\mathrm{kBrPr})$ was varied in a one-step fashion using three settings:

- Continuation of the $20 \%$ for a "moderate" browsing intensity;

- $80 \%$ for an "elevated" browsing intensity to approximate conditions in Swiss forests where ungulate population size is above average (Senn and Suter 2003); and

- $95 \%$ for a "high" browsing intensity to illustrate effect of further increasing ungulate populations (Senn and Suter 2003).

According to the aim of current ungulate management practices to maintain animal populations constant (Senn and Suter 2003), we assumed constant browsing intensity over time.

In order to separate the effects of browsing and climate change, one set of simulations was done only varying browsing pressure but using current climate conditions. A second set of simulations was performed by varying browsing pressure in combination with a change in climate.

We assumed the changes in climate to occur in a linear fashion, whereby the transient climate change was simulated over a period of 100 years, i.e., starting after the spin-up (year 3000) and reaching the new steady climate (future climate, Section 2.3.2) in the simulation year 3100. The simulations were then continued with 
this new climate state for another 3,000 years to obtain forests that are in equilibrium with this specific realization of future climate.

\section{Results}

The results presented here for simulated forests under current and future climatic conditions refer to the respective equilibrium conditions. Generally, the model produced an accurate representation of the expected forest types for the current climate (cf. Section 2.1; Figs. 3a, 5a, 6a). Exceptions were the lack of the P. abies belt on the south-facing slope of the Anniviers (Fig. 3a, Section 3.1.1) and the underestimation of Quercus spp. in the Maggia valley (Fig. 6a, Section 3.3.1). Our estimations of basal area, stem numbers and species compositions are not predictions or projections, but represent a few possible scenarios of forest development, assuming the three different browsing scenarios and one realization of climate change.

\subsection{Western Central Alps}

\subsubsection{Current climate}

Based on the control run with no change in browsing and climate, drought-resistant $P$. sylvestris and Quercus spp. dominated the forests at the valley bottom of the Val d'Anniviers (basal area [BA] ca. 20 to $25 \mathrm{~m}^{2} / \mathrm{ha}$, Fig. 3a) and up to the montane zone of the south-facing slope (BA ca. 25 to $30 \mathrm{~m}^{2} /$ ha, Fig. 3a). On the north-facing slope, Quercus spp. and $P$. sylvestris were replaced with increasing elevation by deciduous species such as $F$. sylvatica intermixed with $A$. alba (BA ca. $30 \mathrm{~m}^{2} /$ ha, Fig. $3 a$ ), and further up by $P$. abies, which dominated the high-montane and subalpine plots up to ca. $2200 \mathrm{~m}$ a.s.l. (BA ca. $35 \mathrm{~m}^{2} /$ ha, Fig. 3a). On both slopes, P. cembra and to a lesser extent $L$. decidua formed the forests at higher elevations (BA $<1$ to ca. $20 \mathrm{~m}^{2} / \mathrm{ha}$, Fig. 3a).

\subsubsection{Effect of changes in browsing}

On many plots along the transect, changes in browsing pressure led to shifts in the relative and absolute abundance of the dominant and sub-dominant species (Fig. 3b, c), whereby A. alba, F. sylvatica and P. cembra were affected most. The resulting loss in basal area was not uniform (i.e., $1-15 \mathrm{~m}^{2} / \mathrm{ha}$, Fig. $3 \mathrm{~b}, \mathrm{c}$ ) and it was only partially compensated by other species. Interestingly, although Quercus spp. are sensitive to browsing $(k$ Brow $=4$, Table 2$)$, they remained part of the forest community even under high browsing pressure. As light-demanding species, they profited from the increased light availability in the intensively browsed forests (Fig. 3c).

\subsubsection{Effect of changes in climate}

Keeping browsing pressure constant at a moderate intensity but changing the climate resulted in a collapse of the forest in the valley bottom (Fig. 4c), where only $P$. sylvestris was able to survive in some plots with a resulting drop in basal area from $>20$ to $<5 \mathrm{~m}^{2} /$ ha (Fig. $3 \mathrm{~d}$ ). Compared to conditions under current climate, climate change forced an upslope shift of species ranges (Fig. 3d): (1) on the south-facing slope, the Quercus spp.-P. sylvestris forests were found at much higher elevations (up to upper current treeline); (2) on the north-facing slope $P$. abies with some $A$. alba, both typical species of the current montane level (cf. Fig. 3a) were found at the 

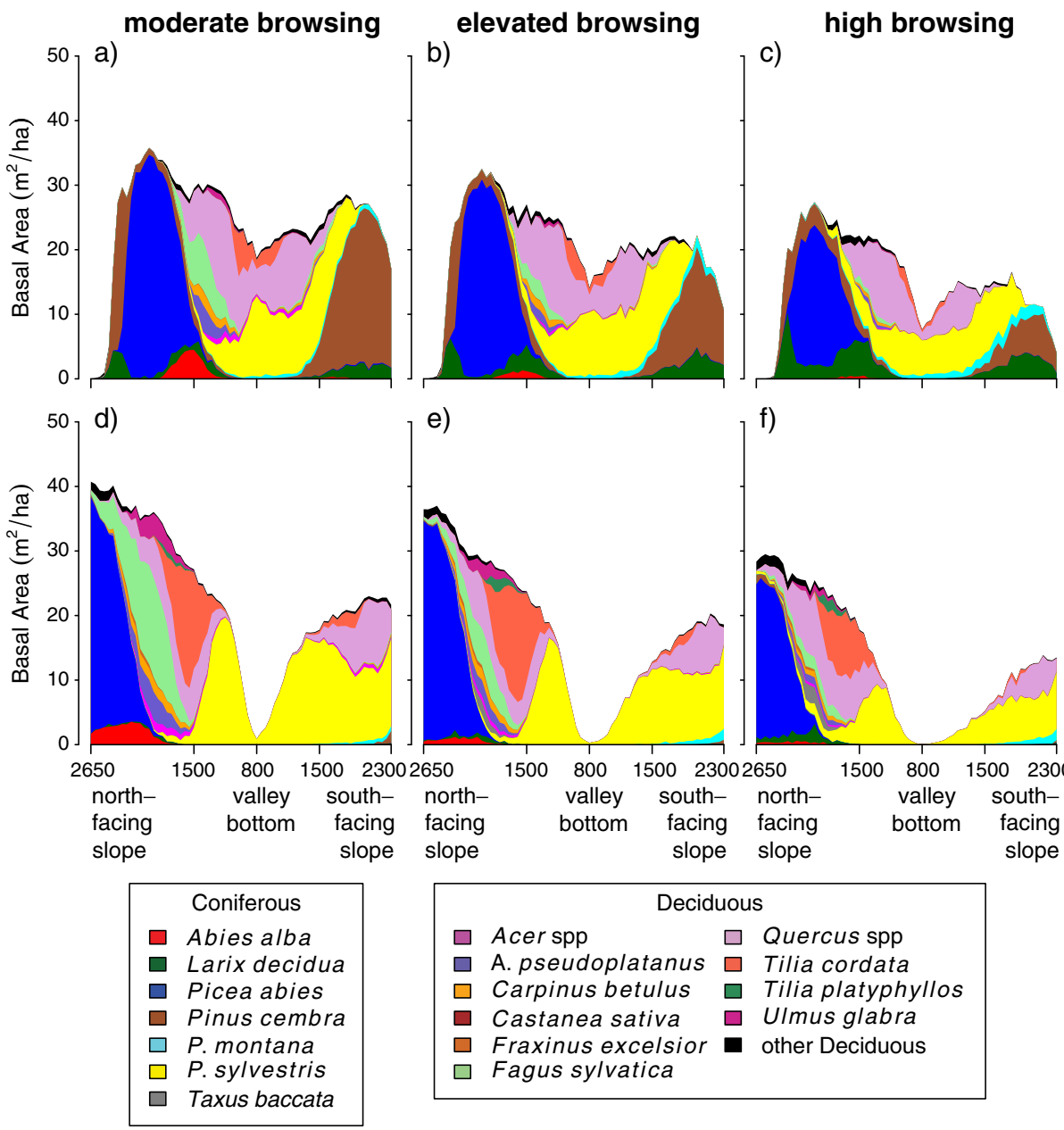

e)

f)

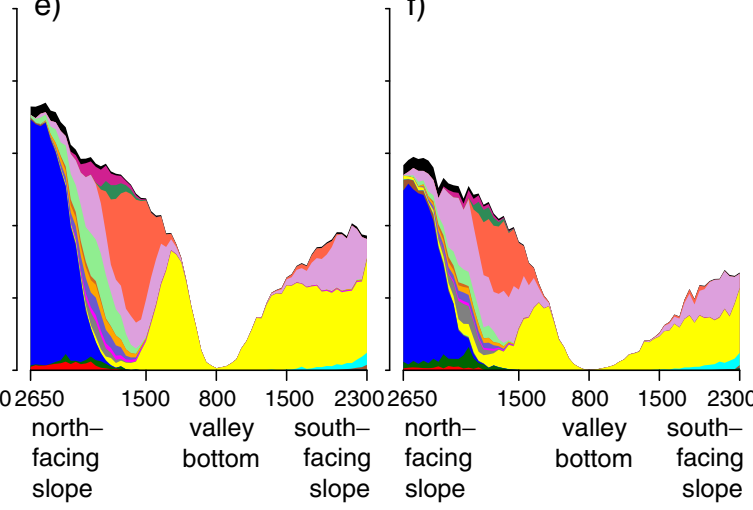

Fig. 3 Basal area along the transect in the Anniviers valley (dry and continental climate) after 3,000 years of spin-up under current climate and moderate browsing pressure $(\mathrm{kBr} P r)$ for: a-c additional 3,100 years under current climate for three different browsing pressures and; d-f after 100 years of climate transition $+3,000$ years under the new climate for three different browsing pressures. "Other deciduous" include: Alnus glutinosa, A. incana, A. viridis, Betula pendula, Populus nigra, $P$. tremula, Salix alba, Sorbus aria, S. aucuparia. The graph displays the results of 68 independent simulations for the elevation plots along the transect (cf. Section 2.3)

elevation of the current treeline and above; (3) due to this increase of P. abies and A. alba, species forming the current upper treeline ( . cembra and L. decidua) declined; and (4) on the north-facing slope new forest types, dominated by Tilia cordata and Quercus spp., formed in what is currently the lower montane belt.

\subsubsection{Effect of changes in browsing and climate}

An increase in browsing pressure in addition to climate change led again to a strong reduction in $A$. alba and F. sylvatica but not of Quercus spp. (Fig. 3e, f). 
Furthermore, browsing exacerbated the collapse of the forests in the valley bottom (Fig. 3e, f and 4c, d). Elevated browsing pressure delayed forest development above current treeline on the north-facing slope, so that at the end of the climate transition (100 years after spin-up), simulated basal area was about twice as high under moderate browsing (Fig. 4e) compared to elevated browsing (Fig. 4f). On the south-facing slope, the climate change-induced transition from the current subalpine L. deciduas-P. cembra forest to a Quercus spp.-P. sylvestris forest took place over several centuries as $P$. cembra was gradually replaced by new species irrespective of the browsing scenario (Fig. 4a, b).

moderate browsing

a) South-facing Peak $(2300 \mathrm{~m})$

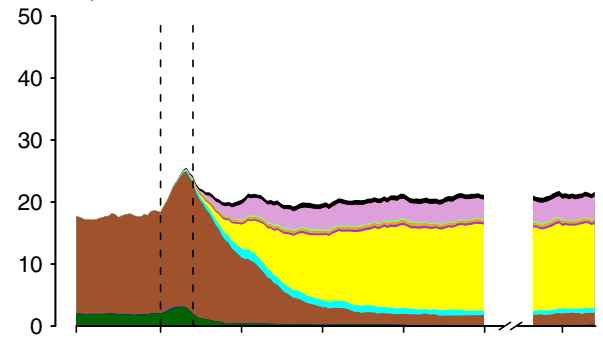

c) Valley Bottom (800m)

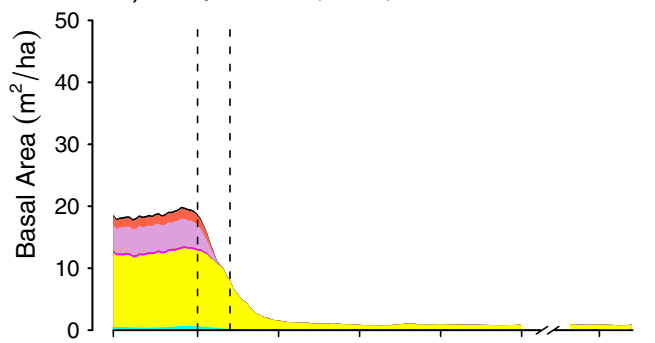

e) North-facing Peak (2650m)

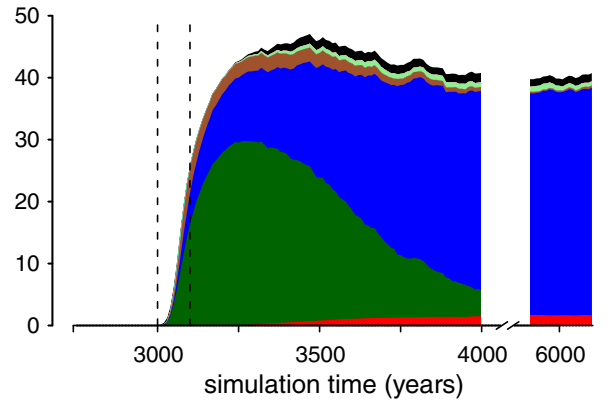

elevated browsing

b) South-facing Peak (2300m)

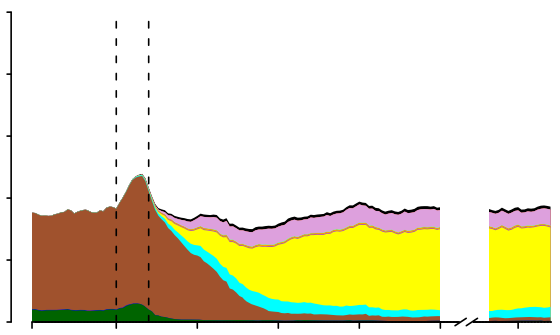

d) Valley Bottom (800m)

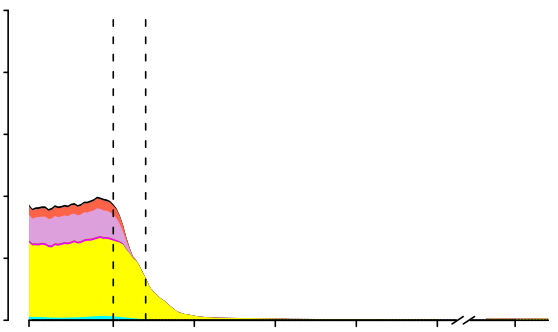

f) North-facing Peak (2650m)

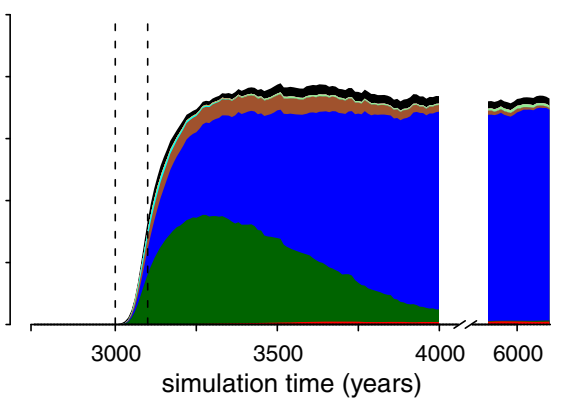

Fig. 4 Forest succession over time in the Anniviers valley for moderate $(k B r P r=20 \%)$ and elevated browsing pressure $(k B r P r=80 \%)$ on the two highest plots on the south-facing $(\mathbf{a}, \mathbf{b})$ and the northfacing slope $(\mathbf{e}, \mathbf{f})$, and for the lowest plot in the valley bottom $(\mathbf{c}, \mathbf{d})$. Dotted lines indicate the end of the spin-up period under current climate coinciding with the start of the climate transition (i.e. first line at simulation year 3000) and end of the climate transition period in simulation year 3100 (second line). Species legend as in Fig. 3 
Total stem numbers differed by a factor of more than two between moderate and elevated browsing pressure at the south-facing slope and in the valley bottom (Table 3). Model behavior near the north-facing peak was different, as it was above treeline under current climate; although basal area was developing at a lower rate under high browsing pressure (Fig. 4e, f), stem number was not affected by browsing after 100 years of climate transition (Table 3). The 115 trees per hectare that were estimated by the model for the north-facing peak (Table 3) are an artifact of the model simulations due to the representation of the establishment process: small trees are established as soon as climate permits, even though they may not be able to grow; their total basal area amounted to merely $0.03 \mathrm{~m}^{2} / \mathrm{ha}$.

\subsection{Eastern Central Alps}

\subsubsection{Current climate}

In the Tuors valley, forests did not grow along the whole transect, as the cold treeline was reached on both the south-facing and the north-facing slopes at ca. 2,400 m (Fig. 5a). Treeline forests were formed by L. decidua and P. cembra, while P. abies dominated the forests towards the valley bottom (Fig. 5a). Basal area reached a maximum of approximately $38 \mathrm{~m}^{2} /$ ha in the valley bottom and gradually decreased until treeline was reached (Fig. 5a). Similarly to the Anniviers valley, trees were able to establish above treeline (Table 3 ), but unable to grow.

\subsubsection{Effect of changes in browsing}

Higher browsing pressure led to a ca. $25 \%$ decrease in the basal area of the dominant $P$. abies (Fig. 5c). The concurrent increase in available light resulted in a considerable $50 \%$ gain in basal area of $P$. cembra and L. deciduas, which are more light-demanding

Table 3 Total stem numbers per hectare on the two highest plots on the south-facing and northfacing slopes and on the plot in the valley bottom for all three transects under moderate (i.e., 20\%) and elevated (i.e., $80 \%$ ) browsing pressure

\begin{tabular}{|c|c|c|c|c|c|}
\hline \multirow{2}{*}{$\begin{array}{l}\text { Year } \\
\text { Browsing pressure }\end{array}$} & \multirow{2}{*}{$\begin{array}{l}3000 \\
\text { Moderate }\end{array}$} & \multicolumn{2}{|l|}{3100} & \multicolumn{2}{|l|}{6100} \\
\hline & & Moderate & Elevated & Moderate & Elevated \\
\hline \multicolumn{6}{|l|}{ Anniviers valley } \\
\hline South-facing $(2,249 \mathrm{~m})$ & 504 & 905 & 435 & 1671 & 802 \\
\hline Valley (854 m) & 1820 & 525 & 215 & 246 & 73 \\
\hline North-facing $(2,564 \mathrm{~m})$ & $115^{\mathrm{a}}$ & 1213 & 1160 & 838 & 603 \\
\hline \multicolumn{6}{|l|}{ Tuors valley } \\
\hline South-facing $(2,715 \mathrm{~m})$ & $9^{\mathrm{a}}$ & 1776 & 1076 & 810 & 561 \\
\hline Valley $(1,717 \mathrm{~m})$ & 836 & 1713 & 1002 & 2006 & 1318 \\
\hline North-facing $(2,540 \mathrm{~m})$ & $20^{\mathrm{a}}$ & 1666 & 1174 & 707 & 547 \\
\hline \multicolumn{6}{|l|}{ Maggia valley } \\
\hline South-facing $(2,091 \mathrm{~m})$ & 807 & 961 & 682 & 1736 & 1108 \\
\hline Valley (367 m) & 2128 & 2161 & 1312 & 1819 & 986 \\
\hline North-facing $(2,061 \mathrm{~m})$ & 748 & 964 & 645 & 1698 & 1073 \\
\hline
\end{tabular}

Data are presented for current climate (i.e., year 3000), after the transition to the new climate (i.e., year 3100) and after additional 3,000 years under the future climate (i.e., year 6100)

${ }^{a}$ Plots above treeline where trees can establish but not persist, which resulted in the reported numbers of very small stem 

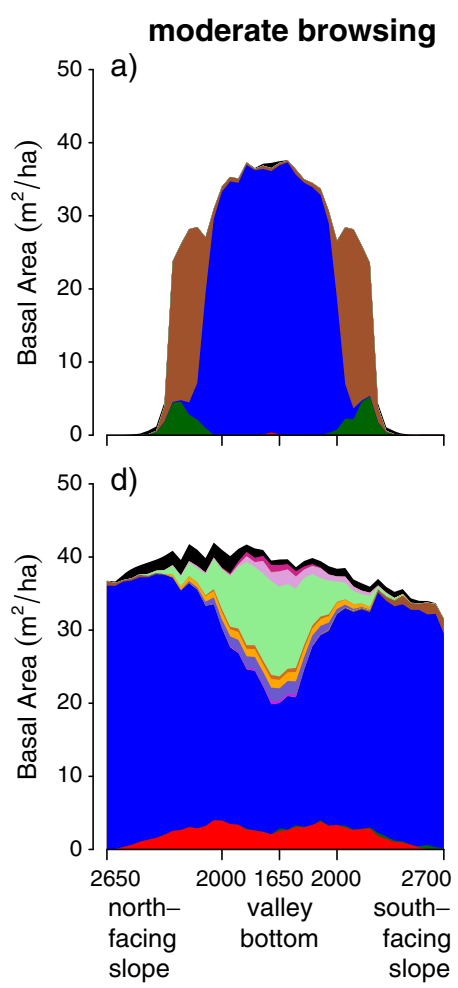

elevated browsing

b)

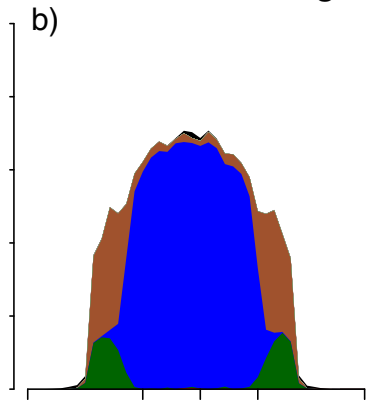

e)

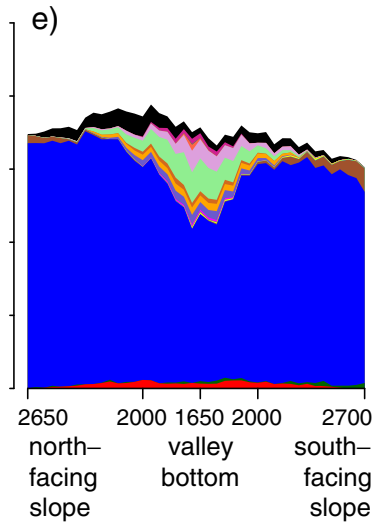

c)

high browsing

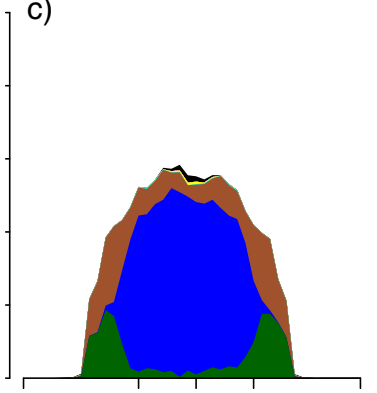

f)

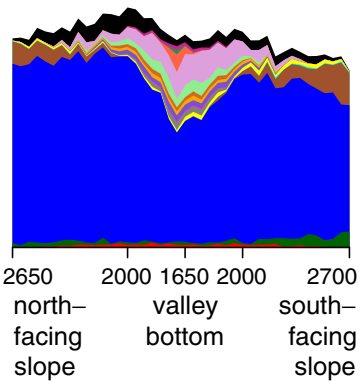

Fig. 5 Transect in the Tuors valley (moist and cold climate); for details and species legend see Fig. 3. The graph displays the results of 42 independent simulations for the elevation plots along the transect (cf. Section 2.3)

than $P$. abies (Fig. 5b, c), thus leading to a co-dominance by $P$. cembra at lower elevations.

\subsubsection{Effect of changes in climate}

Climate change caused a shift of tree species by approximately 1,000 m upslope. The forest that developed at current treeline (i.e., ca. 2,400 m, Fig. 5a) is typical for forests found today at the transition from high-montane to subalpine conditions, i.e., dominance of $P$. abies with some P. cembra (Fig. 5a, d). Under the changed climate, forests covered the entire transect, as the cold treeline moved beyond the highest elevations of the transect. In the valley bottom, forest types developed that were dominated by $F$. sylvatica and P. abies (Fig. 5d). The temporal development of forests above current treeline under the assumed change in climate proceeded in a similar way as on the north-facing peak in the Anniviers valley (Fig. 4e), moving through an early-successional $L$. decidua forest to dominance by $P$. abies interspersed with $P$. cembra trees (results not shown). Below ca. 2,500 m, deciduous species including F. sylvatica, A. pseudoplatanus, Quercus spp., and T. cordata together with $A$. alba started to replace $P$. abies with the onset of climate change. 


\subsubsection{Effect of changes in browsing and climate}

Browsing pressure had a strong influence on the change in tree species composition following climate change. The increase in browsing pressure led to a decrease of $F$. sylvatica (Fig. 5e, f). Additionally, the abundance of browsing-sensitive but relatively shade-tolerant tree species such as $A$. alba and $A$. pseudoplatanus was reduced strongly, whereas the browsing-sensitive but more light-demanding Quercus spp. and $P$. cembra gained importance with increasing browsing pressure (Fig. 5e, f). An increase in browsing pressure from a moderate to a high level led to a reduction in stem numbers by ca. $30 \%$ (cf. Table 3 ).

\subsection{Southern Alps}

\subsubsection{Current climate}

Under current climate the simulated subalpine $P$. abies forest in the Maggia valley extended down to ca. 1,700 $\mathrm{m}$ on both slopes (Fig. 6a). With decreasing elevation, the forest changed gradually to an $A$. alba-F. sylvatica-P. abies forest, and eventually to a deciduous forest dominated by $F$. sylvatica, $C$. sativa, A. pseudoplatanus, Tilia

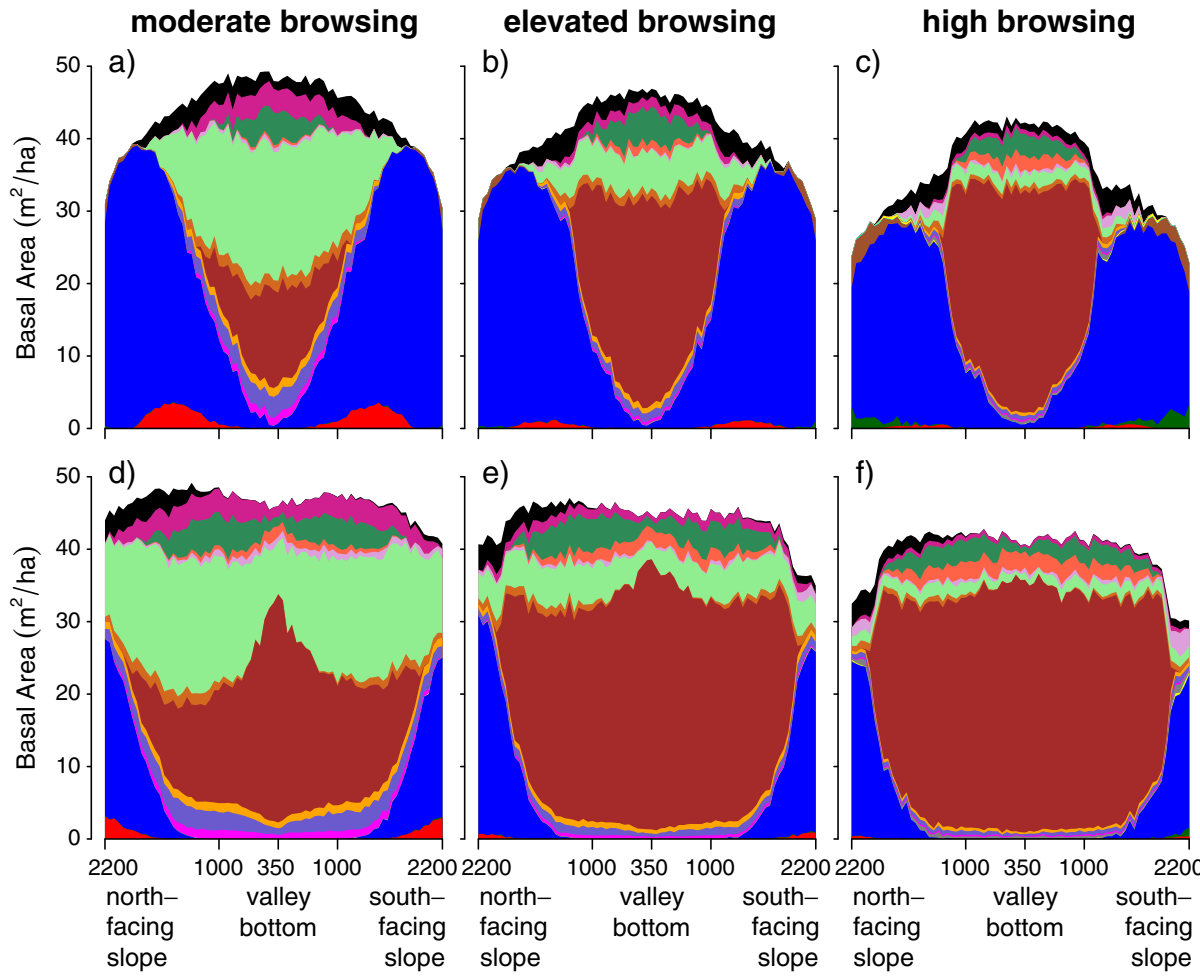

Fig. 6 Transect in the Maggia valley (moist and warm climate); for details and species legend see Fig. 3. The graph displays the results of 75 independent simulations for the elevation plots along the transect (cf. Section 2.3) 
platyphyllos and Ulmus glabra at elevations below ca. 1,000 m (Fig. 6a). In the model, favorable climatic conditions allowed the establishment of a forest with a total basal area ranging between approximately $30 \mathrm{~m}^{2} /$ ha at the highest elevations to approximately $50 \mathrm{~m}^{2} /$ ha in the valley bottom (Fig. 6a).

\subsubsection{Effect of changes in browsing}

Leaving climate constant while increasing browsing pressure converted the mixed deciduous forests in the valley bottom to stands dominated by $C$. sativa below ca. 1,000 m. At higher elevations, P. cembra became a more abundant species (Fig. 6b, c). A. alba, F. sylvatica, A. pseudoplatanus and $U$. glabra declined with an increase in browsing pressure. The effect of a changing browsing pressure was not linear as the increase from moderate to elevated browsing resulted in an average decrease of basal area by $3 \mathrm{~m}^{2} /$ ha (or $7 \%$ ), while an increase from elevated to high browsing induced an average basal area decrease by $5.5 \mathrm{~m}^{2} /$ ha (or $14 \%$ ).

\subsubsection{Effect of changes in climate}

Similar to the results for the Tuors valley, climate change led to an upslope shift of tree species by approximately $1,000 \mathrm{~m}$. This species shift resulted in a replacement of the former $P$. abies forest by an $A$. alba-F. sylvatica-P. abies forest at the highest plots and below by a deciduous forest dominated by $F$. sylvatica and $C$. sativa, intermixed with Acer spp., A. pseudoplatanus, Carpinus betulus, Fraxinus excelsior, T. platyphyllos, and U. glabra (Fig. 6d). Furthermore, climatic change resulted in an increase in basal area at these elevations (Fig. 6d). In the valley bottom, C. sativa replaced $F$. sylvatica as the dominant species (Fig. 6d).

\subsubsection{Effect of changes in browsing and climate}

Similar to the simulations with an elevated browsing pressure alone (Fig. 6c), combining higher browsing pressure with climate change resulted in a more pronounced dominance of $C$. sativa leading to almost pure $C$. sativa stands (Fig. 6e, f), whereby $C$. sativa reached higher elevations (Fig. 6c, f). Plots at elevations higher than ca. 2,000 m were an interesting exception regardless of the level of browsing pressure. At these elevations $C$. sativa growth was strongly limited due to low winter temperature and low degree-day sums. On these plots, the decrease of $F$. sylvatica due to the increase in browsing was not compensated by other species, which resulted in a reduction of total basal area (Fig. 6e, f).

\subsection{Common pattern}

With increasing browsing pressure, basal area decreased (Figs. 3, 4, 5 and 6), and so did total stem numbers (Table 3). Generally, the effect of browsing was not linear; the decrease in basal area was typically stronger in response to a change from elevated to high browsing pressure (i.e., average ca. 14-40\% depending on the study region) than from moderate to elevated browsing pressure (i.e., average ca. $7-25 \%$ depending on the study region). Along the transects the impact of browsing varied depending on the prevalent species composition and the respective species' sensitivity to browsing. In all three valleys, browsing pressure led to a reduction of the abundance of $A$. alba and F. sylvatica, while interestingly some browsing-sensitive 
but more light-demanding species such as $P$. cembra and Quercus spp. did not suffer correspondingly.

Climate change led to an upslope shift of species and of the cold treeline. In the valley bottom the current forest types were substituted by deciduous trees in the two valleys with moist and wet climate and non-forest vegetation in the dry Anniviers valley. Furthermore, climate change resulted in the formation of new forest types along all transects (Figs. 3, 5 and 6).

Browsing partially counteracted the effects of climate change, for example by retarding forest development at the cold treeline (Fig. 4e, f), but it did amplify the effects of climate change in other plots, for example by exacerbating the collapse of forests near dry treeline (Fig. 4c, d).

\section{Discussion}

\subsection{Current climate}

Generally, the model simulated the expected forest types for the current climate accurately (cf. Sections 2.1, 3.1.1, 3.2.1 and 3.3.1). The dominant species of the different elevation bands from the colline, the montane to the subalpine level were reproduced accurately with two exceptions. First, at mid-elevations on the southfacing slope in the Anniviers valley, $P$. abies forests would have been expected (Gödickemeier 1998; Ott et al. 1997). The missing P. abies belt on this south-facing slope was either due to an overestimation of drought, which in the model strongly limits the establishment and growth of this species, or to an underestimation of its drought tolerance (cf. Table A-10 in Bugmann 1994; Ellenberg 1996). Second, at low elevations in the Maggia valley, the proportion of Quercus spp. should have been higher, reflecting the extended dry periods in summer that limit the competitiveness of other deciduous species, particularly $F$. sylvatica. This anomaly was probably due to the fact that the monthly climate data used in the model do not fully capture the very high variability of summer precipitation in this part of the Alps, where short thunderstorms often bring heavy precipitation followed by extended periods of drought. See also Giesecke et al. (2010) for the significance of inter-annual climate variability as driver in simulations of vegetation change.

\subsection{Effect of changes in browsing}

First and foremost, increased browsing caused a reduction in total basal area in all three valleys (Figs. 3, 5 and 6), whereby an increase in browsing pressure from "elevated" to "high" levels typically caused a greater decrease in basal area than a shift from moderate to elevated browsing pressure. This finding is not surprising, as it is based on a non-linear function in the model (Fig. 1), but it still corroborates results from other studies that changes in browsing can result in non-linear effects in forest attributes (e.g., Didion et al. 2009a; Kienast et al. 1999).

Second, the impact of changes in browsing pressure on the basal area of individual species and thus on the species composition differed strongly between regions. Particularly in the Anniviers and the Maggia valleys, changes in browsing intensity caused strong shifts in the composition of the dominant species: for example, forests 
in the valley bottom in the Anniviers valley changed from a co-dominance by $P$. sylvestris, Quercus spp. and T. cordata to almost pure P. sylvestris stands (Fig. 3a-c); forests in the Maggia valley changed from $F$. sylvatica dominated stands to $C$. sativa dominated stands (Fig. 6a-f). In contrast, the effect of changes in browsing intensity was less pronounced in the Tuors valley although the simulated browsing intensities were identical in all three valleys. Thus we conclude that the impact of changes in browsing intensity on species composition cannot be extrapolated from one region to others but must rather be evaluated on a regional basis (cf. Didion et al. 2009a).

Third, we sometimes found a positive effect of an increase in browsing pressure on the basal area of shade-intolerant species such as L. decidua (Figs. 3a-c, 5a-c, 6a-c) and P. montana (Fig. 3a-c). These species profited more from the improved light conditions that were induced by the decrease in total basal area than they suffered from the direct effects of browsing. For similar reasons, the reduction in the basal area of the light-demanding Quercus spp. differed between the northfacing and the south-facing slopes in the Anniviers valley (Fig. 3a-c). On the northfacing slope, establishment and growth of Quercus spp. was limited under moderate browsing by low light availability due to the highly shade-casting canopy of P.abies, $A$. alba and $F$. sylvatica (Ellenberg 1996). Under higher browsing pressure, the growth of Quercus spp. profited from the higher light availability due to the decrease in the basal area of those shade-casting species. In contrast, on the south-facing slope Quercus spp. were not light-limited under moderate browsing because the cooccurring $P$. sylvestris had lower basal area and canopy density (Ellenberg 1996). Thus, on the south-facing slope Quercus spp. grew under similar light conditions in all three browsing scenarios, but establishment and hence basal area was increasingly limited when browsing increased. Thus, we conclude that species interactions can strongly modify the net response of tree species to changes in the browsing regime.

Lastly, our results indicate that browsing could cause a decrease in total stem numbers by a factor greater than two (Table 3). A reduction of stem numbers in response to browsing is typically accompanied by a change in the diameter structure of the forest both in the model (cf. Didion et al. 2009a) and in reality (Rossell et al. 2005; cf. Ammer 1996). Such structural changes influence the light regime and hence subsequent regeneration and growth dynamics (Didion et al. 2009a; Rossell et al. 2005; cf. Ammer 1996). Improved light conditions can favor light demanding tree species, as seen for L. decidua, Pinus montana and Quercus spp. Thus, browsing affects species diversity not only directly through the processes of selective feeding, but also indirectly by the alteration of the light regime (cf. Figs. 3, 4, 5 and 6; Ammer 1996; Rooney and Waller 2003; Vavra et al. 2007). These considerations are highly important because in mountain terrain, changes in species composition, forest structure and basal area affect key forest functions such as the protection against avalanches or rockfall (Brang et al. 2001; Dorren et al. 2004; Frehner et al. 2005).

\subsection{Effect of changes in climate}

For the three climatically different valleys, the simulations showed that climate change caused shifts in tree species ranges towards higher elevations (Figs. 3, 5 and 6), which is congruent with observed changes in a variety of taxonomic groups and different geographic locations (Walther et al. 2002; Kullman 2001). The results indicate the absence of gradual movements of forest types (communities) along the 
transects, thus leading to new forest types (e.g., Fig. 3a vs. 3d with a new T. cordatadominated forest). Also, the legacies of the forests that had developed under current climate sometimes strongly affected successional dynamics during and after climate change (Figs. 3, 5 and 6). For example, on the south-facing peak in the Anniviers valley, $P$. cembra first increased in basal area under climatic change before decreasing to sub-dominant status (Fig. 4a, b). This initial increase, which is contrary to the fact that the species is less competitive under the new climatic conditions, is a legacy effect, which can delay the establishment of new species at given locations (cf. Davis 2001; Chauchard et al. 2010).

For a warming of $3.6^{\circ} \mathrm{C}$ to $5.9^{\circ} \mathrm{C}$ (Table 1), an elevational shift of 600 to $1,000 \mathrm{~m}$ could be expected for a lapse rate of $0.6^{\circ} \mathrm{C}$ per $100 \mathrm{~m}$ elevation (cf. Theurillat and Guisan 2001). The simulated species shifts were generally within this range (Figs. 3, 5 and 6). Since the model assumes unlimited seed supply, i.e., it does not address barriers to migration and seed dispersal (cf. Theurillat and Guisan 2001), establishment rates and thus the speed of the upslope shifts are certainly overestimated. Due to the model assumption that soils are always suitable for tree growth, colonization rates for areas well above the current climatic treeline may also be too high. However, land use has been a major driver for the position of the treeline in the Swiss Alps (cf. Gehrig-Fasel et al. 2007), and the existence of alpine meadows and pastures can be expected to be conducive to the establishment of forests after cessation of grazing (Ott et al. 1997). Indeed, Chauchard et al. (2010) found that in parts of the French Alps $A$. alba extended its range upslope by about $300 \mathrm{~m}$ during the last five decades. This is a much faster rate than in our simulations, despite unlimited dispersal in our model.

The replacement of the current high-montane and subalpine forests that are composed of relatively few species by more diverse mixed forests under a warmer climate (Figs. 3, 5 and 6) may be considered positive in terms of biodiversity. However, there will be strong reductions in the area available for alpine species, thus resulting in a higher risk of local extinctions of these species (e.g., P. cembra, Fig. 3d) due to the phenomenon of "summit traps" (cf. Pertoldi and Bach 2007; Theurillat and Guisan 2001). At the other end of the gradient, increasing drought risk can lead to the collapse of forests in some areas (Fig. 4c) as found in empirical studies (e.g., Bigler et al. 2006). The consequences thereof could be a loss of forest species and habitats in theses areas (cf. Davis and Shaw 2001; Theurillat and Guisan 2001) or an influx of invasive species (cf. Hampe and Petit 2005; McCarty 2001). The effects of these processes need to be considered with regard to the change of forest cover and stand types and the consequences for ecosystem services such as timber production and habitat (Millennium Ecosystem Assessment 2005), but also protection from avalanches and rockfalls (Brang et al. 2001; Dorren et al. 2004; Frehner et al. 2005).

\subsection{Effect of changes in browsing and climate}

Typically, the combined effects of climate change and browsing on total basal area along the transects were compensatory, as the reduction in basal area induced by an increase in browsing pressure was lower in the case of climate change than under current climate. The combined effects of climate change and browsing on species composition, however, suggested a dominance of non-compensatory effects. For 
example, an increase in browsing enhanced the dominance by $C$. sativa that followed climatic change in the Maggia valley or led to a species shift (to Quercus spp. rather than to F. sylvatica) at low elevations in the Tuors valley. Thus, an evaluation of the joint effects of climate change and browsing needs to consider species-specific direct (e.g., selective browsing, climatic range) and indirect (e.g., light regime, competition) effects.

Browsing as a "bottom-up" driver of forest dynamics influences tree establishment and thus stem numbers (cf. Table 3; Cairns and Moen 2004) as well as species composition (Figs. 3, 5, 6 and 6). Climate change as a "top-down" process, however, primarily controls the suite of species that is able to establish and affects tree growth and productivity of a forest, as demonstrated by the changes in basal area (cf. Figs. 3 , 4, 5 and 6; Motta et al. 2006). These different drivers controlling stem numbers, species composition and basal area led to the strong combined effect of browsing and climate change as shown in our modeling study, but also in field studies, e.g., in northern Sweden (Cairns and Moen 2004) and Canada (Tremblay et al. 2007). For the shift of species' ranges in response to climate change, browsing thus presents an important factor. Close to treelines, where forests are highly sensitive to disturbance (Davis and Shaw 2001; Hampe and Petit 2005), the effect of browsing can be expected to be most pronounced. For example, we found that browsing exacerbated the climate-induced collapse of forests at the dry treeline, (Fig. 4c, d), whereas it delayed the upward shift of the cold treeline by several decades (Fig. 4e, f).

\subsection{Methodological considerations}

We used only one regionalized data set for one climate change scenario (A1B, cf. IPCC 2007), because our focus was on the joint effects of climate change and browsing intensity rather than a comprehensive analysis of the range of responses under various climate scenarios. While it is likely that other climate scenarios would have shown somewhat different responses of forest ecosystems in the examined valleys, we expect that the demonstrated interactions of climate change and browsing pressure would not vary strongly between climate change scenarios. We therefore conclude that the results from our study characterize the importance of browsing when dealing with the response of forest ecosystems to climate change. Clearly, our results should not be mistaken as predictions of the future state of these systems, but rather as an evaluation of the importance of the processes shaping the long-term population dynamics of forests trees.

\section{Conclusion}

Our study showed that climate change can result in large changes in tree species composition, forest basal area and stem numbers, confirming results from previous modeling studies (e.g., Wallentin et al. 2008; Bugmann 2003; Lexer et al. 2002). We could substantiate and quantify the expected upward shift of tree species (Davis and Shaw 2001; Theurillat and Guisan 2001; Walther et al. 2002; Chauchard et al. 2010) by examining forest development along a continuous elevation transect in three climatically different zones of the Swiss Alps. We did not usually find a 
concurrent movement of today's stand types, but rather remarkable changes in the species composition as well as the development of new stand types.

The simulated shift in tree species ranges due to changes in climate and browsing pressure resulted in changes in habitat types that present major challenges for the management of mountain forest ecosystems. Management practices designed for current forests based on the historical variability in the ecosystem may no longer be appropriate (Millar et al. 2007); alterations in the species composition and the succession to new stand types need to be investigated, and adaptive management strategies need to be developed.

Furthermore, by investigating different browsing regimes, we conclude that while climate change may partially compensate for browsing-induced reductions in basal area, the combined effect of climate change and browsing on the mix of tree species and forest types will probably differ between locations, as browsing selectively excludes species from establishing or reaching dominance (Côté et al. 2004; Rooney and Waller 2003). The responses we found ranged from compensation to enhancement, but they also involved unanticipated feedback loops (e.g., via light availability). Ungulate browsing is only one form of herbivory affecting tree regeneration; other forms of herbivory, for example by insects (Price et al. 2001; Payette and Delwaide 2003; Moen et al. 2004), are expected to add further to the impact of browsing. Since management decisions today have long-term implications with regard to forest succession under climate change (cf. Millar et al. 2007), there is an urgent need for adaptive management strategies that address the combined effects of climate change and both large and small-scale disturbances such as herbivory.

Acknowledgements This research was funded by the Wildlife and Forest Biodiversity Management Section in the Swiss Federal Office for the Environment under contract no. 2004.L.02. Dr. Monika Frehner (Forest Management, Institute of Terrestrial Ecosystems, ETH Zurich) was of great assistance in the revision of the tree species-specific browsing sensitivities. A. Wolf acknowledges funding by the Swiss NCCR Climate (National Center of Excellence in Climate Research). Climatic data were kindly provided by the Land Use Dynamics Research Group at the Swiss Federal Institute for Forest, Snow and Landscape Research (WSL) and by the Institute for Atmospheric and Climate Science, ETH Zurich. We thank Hanspeter Portner (Forest Ecology, Institute of Terrestrial Ecosystems, ETH Zurich) for his assistance in the preparation of the climate data.

Open Access This article is distributed under the terms of the Creative Commons Attribution Noncommercial License which permits any noncommercial use, distribution, and reproduction in any medium, provided the original author(s) and source are credited.

\section{References}

Aas G, Friedrich K (1991) Untersuchungen zur morphologischen Unterscheidung von Stiel- und Traubeneichen. Forest Research 110:349-357

Ammer C (1996) Impact of ungulates on structure and dynamics of natural regeneration of mixed mountain forests in the Bavarian Alps. Forest Ecology and Management 88(1-2):43-53. doi:10.1016/S0378-1127(96)03808-X

Augustine DJ, McNaughton SJ (1998) Ungulate effects on the functional species composition of plant communities: herbivore selectivity and plant tolerance. J Wildl Manage 62(4):11651183 
Bigler C, Bräker O, Bugmann H, Dobbertin M, Rigling A (2006) Drought as an Inciting Mortality Factor in Scots Pine Stands of the Valais, Switzerland. Ecosystems 9(3):330-343. doi:10.1007/s10021-005-0126-2

Brang P, Schönenberger W, Ott E, Garner B (2001) Forests as protection from natural hazards. In: Evans J (ed) The Forests Handbook, vol. 2. Blackwell, Oxford, pp 53-81. doi:10.1002/9780470757079.ch3

Brassel P, Brändli U-B (1999) Schweizerisches Landesforstinventar: Ergebnisse der Zweitaufnahme 1993-1995. Paul Haupt, Bern

Bugmann H (1994) On the ecology of mountainous forests in a changing climate: a simulation study. PhD Thesis No. 10638, Swiss Federal Institute of Technology (ETHZ), Zürich. http://e-collection.ethbib.ethz.ch/view/eth:22365

Bugmann HKM (1996) A simplified forest model to study species composition along climate gradients. Ecology 77:2055-2074

Bugmann H (2003) Predicting the ecosystem effects of climate change. In: Canham CD, Lauenroth WK, Cole JS (eds) Models in ecosystem science. Princeton University Press, Princeton, pp 385409

Bugmann HKM, Solomon AM (2000) Explaining forest composition and biomass across multiple biogeographical regions. Ecol Appl 10:95-114

Cairns DM, Moen J (2004) Herbivory influences tree lines. J Ecol 92(6):1019-1024. doi:10.1111/ j.1365-2745.2004.00945.x

Cairns D, Lafon C, Moen J, Young A (2007) Influences of animal activity on treeline position and pattern: implications for treeline responses to climate change. Phys Geogr 28 (5):419-433. doi:10.2747/0272-3646.28.5.419

Chauchard S, Beilhe F, Denis N, Carcaillet C (2010) An increase in the upper tree-limit of silver fir (Abies alba Mill.) in the Alps since the mid-20th century: A land-use change phenomenon. For Ecol Manag 259(8):1406-1415. doi:10.1016/j.foreco.2010.01.009

Côté SD, Rooney TP, Tremblay J-P, Dussault C, Waller DM (2004) Ecological impacts of deer overabundance. Ann Rev Ecolog Syst 35:113-147

Davis MB (2001) Past and future forest response to rapid climate change. In: Schulze E-D, Heimann M, Harrison S et al. (eds) Global biogeochemical cycles in the climate system. Academic, San Diego, pp 167-175

Davis MB, Shaw RG (2001) Range shifts and adaptive responses to Quaternary climate change. Science 292(5517):673-679. doi:10.1126/science.292.5517.673

Didion M (2009) The role of changes in regeneration dynamics for tree species composition and diameter structure in forests. PhD Thesis No. 18398, Swiss Federal Institute of Technology (ETHZ), Zürich. http://e-collection.ethbib.ethz.ch/view/eth:587

Didion M, Kupferschmid AD, Bugmann H (2009a) Effects of ungulate browsing on forest composition and structure-a model sensitivity analysis. For Ecol Manag 258S:S44-S55. doi:10.1016/j.foreco.2009.06.006

Didion M, Kupferschmid AD, Lexer MJ, Rammer W, Seidl R, Bugmann H (2009b) Potentials and limitations of using large-scale forest inventory data for evaluating forest succession models. Ecol Model 220:133-147. doi:10.1016/j.ecolmodel.2008.09.021

Didion M, Kupferschmid AD, Zingg A, Fahse L, Bugmann H (2009c) Gaining local accuracy while not losing generality-extending the range of gap model applications. Can J For Res 39:10921107. doi:10.1139/X09-041

Dorren LKA, Berger F, Imeson AC, Maier B, Rey F (2004) Integrity, stability and management of protection forests in the European Alps. For Ecol Manag 195:165-176

EAFV (Eidgenössische Anstalt für das forstliche Versuchswesen), BFL (Bundesamt für Forstwesen und Landschaftsschutz) (eds) (1988) Schweizerisches Landesforstinventar: Ergebnisse der Erstaufnahme 1982-1986. Ber. Eidgenöss. Forsch. Anst. Wald Schnee Landsch. 305. Eidg. Anstalt für das forstliche Versuchswesen, Birmensdorf

Eiberle K, Nigg H (1987) Grundlagen zur Beurteilung des Wildverbisses im Gebirgswald. Schweizerische Zeitschrift für Forstwesen 138:747-785

Ellenberg H (1996) Vegetation Mitteleuropas mit den Alpen in ökologischer, dynamischer und historischer Sicht, 5th edn. Ulmer, Stuttgart

Frehner M, Wasser B, Schwitter R (2005) Nachhaltigkeit und Erfolgskontrolle im Schutzwald Wegleitung für Pflegemassnahmen in Wäldern mit Schutzfunktion. Bundesamt für Umwelt, Wald und Landschaft (BUWAL), Bern 
Gehrig-Fasel J, Guisan A, Zimmermann NE (2007) Tree line shifts in the Swiss Alps: climate change or land abandonment? J Veg Sci 18 (4):571-582. doi:10.1658/1100-9233(2007) 18[571:TLSITS]2.0.CO;2

Giesecke T, Miller PA, Sykes MT, Ojala AEK, Seppä H, Bradshaw RHW (2010) The effect of past changes in inter-annual temperature variability on tree distribution limits. J Biogeogr 37(7):1394-1405. doi:10.1111/j.1365-2699.2010.02296.x

Gobet E, Tinner W, Hubschmid P, Jansen I, Wehrli M, Ammann B, Wick L (2000) Influence of human impact and bedrock differences on the vegetational history of the Insubrian Southern Alps. Veg Hist Archaeobot 9(3):175-187. doi:10.1007/BF01299802

Gödickemeier I (1998) Analyse des vegetationsmusters eines zentralalpinen Bergwaldgebiets. PhD Thesis No. 12641, Swiss Federal Institute of Technology (ETHZ), Zürich; http://e-collection. ethbib.ethz.ch/view/eth:22617

Grace J, Berninger F, Nagy L (2002) Impacts of climate change on the tree line. Ann Bot 90(4):537544

Hampe A, Petit RJ (2005) Conserving biodiversity under climate change: the rear edge matters. Ecology Letters 8(5):461-467. doi:10.1111/j.1461-0248.2005.00739.x

Hewitt CD, Griggs DJ (2004) Ensembles-based predictions of climate changes and their impacts (ENSEMBLES). Eos 85(52). doi:10.1029/2004EO520005

Intergovernmental Panel on Climate Change (2007) Climate change 2007: synthesis report. Contribution of working groups I, II and III to the fourth assessment report of the intergovernmental panel on climate change [Core writing team, Pachauri, RK and Reisinger, A (eds)]. IPCC, Geneva, Switzerland

Kienast F, Fritschi J, Bissegger M, Abderhalden W (1999) Modeling successional patterns of highelevation forests under changing herbivore pressure-responses at the landscape level. For Ecol Manag 120:35-46

Kullman L (2001) 20th century climate warming and tree-limit rise in the Southern Scandes of Sweden. AMBIO 30(2):72-80

Lexer MJ, Hönninger K, Scheifinger H, Matulla C, Grollb N, Kromp-Kolb H, Schadauer K, Starlinger F, Englisch M (2002) The sensitivity of Austrian forests to scenarios of climatic change: a large-scale risk assessment based on a modified gap model and forest inventory data. For Ecol Manag 162:53-72

Lock S, Pahlmann S, Weber P, Rigling A (2003) Nach Stalden kehren die Flaumeichen zurück. Wald und Holz 9:29-33

McCarty JP (2001) Ecological consequences of recent climate change. J Soc Conserv Biol 15(2):320331. doi:10.1046/j.1523-1739.2001.015002320.x

Millar CI, Stephenson NL, Stephens SL (2007) Climate change and forests of the future: managing in the face of uncertainty. Ecol Appl 17:2145-2151. doi:10.1890/06-1715.1

Millennium Ecosystem Assessment (2005) Ecosystems and Human Well-being: Synthesis. Island Press, Washington

Moen J, Aune K, Edenius L, Angerbjörn A (2004) Potential effects of climate change on treeline position in the Swedish mountains. Ecology and Society 9(1):16. (online URL: http://www.ecologyandsocietyorg/vol9/iss1/art16/)

Motta R, Morales M, Nola P (2006) Human land-use, forest dynamics and tree growth at the treeline in the Western Italian Alps. Ann For Sci 63(7):739-747. doi:10.1051/forest:2006055

Ott E, Frehner M, Frey H-U, Lüscher P (1997) Gebirgsnadelwälder - Ein praxisorientierter Leitfaden für eine standortgerechte Waldbehandlung. Verlag Paul Haupt, Bern

Payette S, Delwaide A (2003) Shift of conifer boreal forest to lichen-heath parkland caused by successive stand disturbances. Ecosystems 6:540-550

Pertoldi C, Bach LA (2007) Evolutionary aspects of climate-induced changes and the need for multidisciplinarity. J Therm Biol 32(3):118-124. doi:10.1016/j.jtherbio.2007.01.011

Price DT, Zimmermann NE, van der Meer PJ, Lexer MJ, Leadley P, Jorritsma ITM, Schaber J, Clark DF, Lasch P, McNulty S, Wu J, Smith B (2001) Regeneration in gap models: priority issues for studying forest responses to climate change. Clim Change 51:475-508

Risch AC, Heiri C, Bugmann H (2005) Simulating structural forest patterns with a forest gap model: a model evaluation. Ecol Model 181:161-172

Rooney TP, Waller DM (2003) Direct and indirect effects of white-tailed deer in forest ecosystems. For Ecol Manag 181:165-176

Rossell Jr. CR, Gorsira B, Patch S (2005) Effects of white-tailed deer on vegetation structure and woody seedling composition in three forest types on the Piedmont Plateau. For Ecol Manag 210:415-424 
Senn J, Suter W (2003) Ungulate browsing on silver fir (Abies alba) in the Swiss Alps: beliefs in search of supporting data. For Ecol Manag 181:151-164

Shao G, Bugmann H, Yan X (2001) A comparative analysis of the structure and behavior of three forest gap models at sites in northeastern China. Clim Change 51:389-413

Theurillat J-P, Guisan A (2001) Potential impact of climate change on vegetation in the European Alps: a review. Clim Change 50(1):77-109. doi:10.1023/A:1010632015572

Thornton PE, Running SW, White MA (1997) Generating surfaces of daily meterological variables over large regions of complex terrain. J Hydrol 190:214-251

Thuiller W, Lavorel S, Araújo MB, Sykes MT, Prentice IC (2005) Climate change threats to plant diversity in Europe. Proceedings of the National Academy of Sciences of the United States of America 102(23):8245-8250. doi:10.1073/pnas.0409902102

Tremblay J-P, Huot J, Potvin F (2007) Density-related effects of deer browsing on the regeneration dynamics of boreal forests. J Appl Ecol 44 (3):552-562. doi:10.1111/j.1365-2664.2007.01290.x

Vavra M, Parks CG, Wisdom MJ (2007) Biodiversity, exotic plant species, and herbivory: the good, the bad, and the ungulate. For Ecol Manag 246:66-72

Wallentin G, Tappeiner U, Strobl J, Tasser E (2008) Understanding alpine tree line dynamics: an individual-based model. Ecol Model 213(3-4):235-246. doi:10.1016/j.ecolmodel.2008.07.005

Walther GR, Post E, Convey P (2002) Ecological responses to recent climate change. Nature 416(28):389-395 